\title{
RESILIENCE, LIFE SATISFACTION AND \\ FORGIVENESS OF PROSPECTIVE PSYCHOLOGICAL COUNSELORS
}

\section{RESILIENCIA, SATISFACCIÓN DE LA VIDA Y PERDÓN DE LOS FUTUROS CONSEJEROS PSICOLÓGICOS}

\author{
Yağmur Çerkez $^{1^{*}}$, İjlal Öztörel ${ }^{2}$ \\ ${ }^{I}$ Near East University, Facuty of Education, Department of Psychological \\ Counseling and Guidance, North Cyprus \\ Email: yagmur.cerkez@neu.edu.tr \\ ${ }^{2}$ Social Services Department, Ministry of Health, North Cyprus
}

Enviado: 27 de junio de 2019

Aceptado para publicar: 30 de julio de 2019

Publicado: 8 de agosto de 2019

\begin{abstract}
The main aim of this study is to examine resilience, life satisfaction and forgiveness levels of prospective psychological counselors. In this context, gender and number of siblings were examined for any differences. Mann-Whitney U test, Kruskal-Wallis test, and Spearman correlation analysis were conducted. It was observed that resilience, life satisfaction, forgiveness, and forgiveness sub-dimensions were positively related. The findings revealed a significant difference in forgiveness and life satisfaction. Females had significantly higher life satisfaction, whereas males had significantly higher forgiveness levels. In terms of number of siblings, those who were single child exhibited higher levels of life satisfaction than those who have who have five or more siblings. Finally, there was a significant correlation between forgiveness, life satisfaction and resilience. The findings are discussed in the light of previous studies in the literature.
\end{abstract}

Keywords: Resilience, life satisfaction, forgiveness, prospective counselors.

El objetivo principal de este estudio es examinar los niveles de resiliencia, satisfacción con la vida y perdón de los posibles consejeros psicológicos. En este contexto, se examinó el género y el número de hermanos en busca de diferencias. Se realizaron la prueba U de MannWhitney, la prueba de Kruskal-Wallis y el análisis de correlación de Spearman. Se observó que las subdimensiones de resiliencia, satisfacción con la vida, perdón y perdón estaban positivamente relacionadas. Los hallazgos revelaron una diferencia significativa en el perdón y la satisfacción con la vida. Las mujeres tenían una satisfacción con la vida significativamente mayor, mientras que los hombres tenían niveles de perdón significativamente más altos. En términos de número de hermanos, aquellos que eran hijos solteros exhibieron niveles más altos de satisfacción con la vida que aquellos que tienen cinco o más hermanos. Finalmente, hubo una correlación significativa entre el perdón, la satisfacción con la vida y la resistencia. Los hallazgos se discuten a la luz de estudios previos en la literatura.

Palabras clave: Resiliencia, satisfacción con la vida, perdón, posibles consejeros. 


\section{Introduction}

As social beings, humans, from birth to death, keep going through several stages of development, and prepare themselves for the following stages of their life. They are always interacted in life and face negative or positive situations. Several stress factors test their resilience, strenghten or weaken it. Individuals wish to be happy, adapt to the social environment they belong to and be appreciated.

An individual's resilience, in this process, is a crucial factor. Individuals experiencing negative events such as economical depreviation, psychological or physical violence, natural disasters like earthquakes or floods, socioeconomically needy family structure, lost lives in terrorism activities, and war are in the risk group.

Resilience exhibited by individuals against difficulties and negative events may vary according to the structure of families from birth onwards and external factors emerging from school or the social environment. While examining individuals' resilience, several risks such as economical depreviation, loss of parent (s) or parents' serious health problems, experiencing natural disasters etc. need to be considered together. While doing so, it should not be forgotton that multi-risk factors may be effective on resilience.

Recent studies in resilience focused on the effect of several risks rather than considering the negative result of a single risk and protective factors strengthening resilience (Masten et al, 2003; Leung \& Chan, 2016). The protective factors can be discussed in two categories, internal and external. Respect to a strong self-esteem, optimism, positive nature, self-efficacy, good communication skills, and inner control are considered as internal protective factors (Eminağaoğlu, 2006: Murray, 2003; Barbosa, 2018). McCubbin (2001; Murray, 2003) on the other hand, lists social and economical prosperity, educated and working parents, positive and supportive family relationships, and constructive school environments as external factors.

Studies in self well-being examine how and why individuals evaluate their private life styles positively. These studies deal with life satisfaction, positive feelings, happiness and morality concepts (Özgen, 2012; Farzadnia et al, 2017). Several ways of increasing lifestyles and satisfaction have bees seeked. Developments in medicine, occupations like meditation, technological innovations used in daily life can be examples to raising happiness and feeling better (Sarıcaoğlu, 2011; Hakiminya \& Parnian, 2018). Life satisfaction, forming the cognitive side of self well-being reflects an individual's overall satisfaction with life. Life satisfaction repondiing to an individual's life is the result of the comparison of the present situation and expectations from life. In other words, life satisfaction can be achieved by comparing an individual's wishes and what is owned (Özgen, 2012; Mehrabifar et al, 2017; Al Tariq, 2018).

Forgiveness is as important as resilience and life satisfaction in leading a comfortable life. We interact with others when we socialize. We may have experienced joy, excitement, restlessness, or resentment throughout our life. If our experiences offend us, it may interrup the flow of our life. At this point, "forgiveness" concept steps in. Enright defines forgiveness as an "uncoditional present to the person who hurts you" (Enright, 1994).

"Forgiveness" can be described as an approach eliminating all the negative feelings hindering the flow of our life to an extent. "Forgiveness" concept is discussed in three dimensions; "forgiveness of self", "forgiveness of others", and "forgiveness of situation" (Thompson et al, 2005; Zendegany et al, 2019). "Forgiveness of self" is defined as minimizing one's resentment and anger replacing them with positive feelings (Hall \& Fincham, 2005). "Forgiveness of others", on the other hand, is motivating pitying, sharing, and loving feelings and one's voluntarily shaking of all the anger and judgement towards others (Enright, 1996). Turning negative reactions into positive or neutral is another way of forgiveness (Thomson et al., 2005; Yaghoubi Nezhad et al, 2019).

Within the counseing process, psychological counselors have to accept their clients as they are and they should not judge them. This is very important for the counseling process to be successful. Therefore, it is important to examine prospective counseling forgiveness (Mostafavi et al, 2019; Eissazadeh et al, 2019).

The aim of this research is to examine the relationship between resilience, life satisfaction and forgiveness of prospective psychological counselors through different variables. The following questions have been asked;

1. Is there a difference between prospective psychological counselors' level of resilience, life satisfaction and forgiveness based on gender and number of siblings?

2. Is there a relationship between life satisfaction, forgiveness and resilience scores of prospective counselors?

\section{Methods}

\section{Research Design}

This is a descriptive research aiming to specify the relationship between resilience, life satisfaction, and forgiveness levels of psychological counseling and guidance students' forgiveness. A quantitative method was used in this study. 
Survey models are approaches to describe a past or current event without any alterations (Karasar,2000; Villalobos, 2018).

\section{Participants}

The participants were the 3rd and 4th year psychological counceling and guidance students at Near East university, Lefkoşa, TRNC (Turkish Republic of North Cyprus). 234 students were picked through simple sampling method (Table 1).

Table 1. Demographic information of participants

\begin{tabular}{lll}
\hline & N & \% \\
\hline Gender & & \\
Female & 116 & 49,57 \\
Male & 118 & 50,43 \\
\hline Number of siblings & & \\
Single child & 10 & 4,27 \\
1-2 siblings & 57 & 24,36 \\
3-4 siblings & 88 & 37,61 \\
5 or more siblings & 79 & 33,76 \\
\hline Birth order & & \\
First child & 73 & 31,20 \\
Second child & 67 & 28,63 \\
Third child & 33 & 14,10 \\
Fourth child or later & 61 & 26,07 \\
\hline
\end{tabular}

\section{Data Collection Tools}

A questionnaire consisting of four parts; Personal Information, Resilience Scale, Life Satisfaction Scale, and Heartland Frogiveness Scale was used to collect data.

\section{Personal Information Form}

This form, prepared by the researcher, deals with the Psychological Counseling and Guidance (PCG) students' demographic characteristics such as, gender, number of siblings, and birth order.

\section{The Resilience Scale}

The Resilience Scale, developed by Block \& Kremen (1996), and adapted into Turkish by Karairmak (2007), was used to specify the resilience levels of PCG students. The scale consisted of 14 propositions in 4 ratings. The responses were rated as, " "Doesn't suit at all"=1 point, "it sometimes suits" $=2$ points, "it suits in general" $=3$ points, and "it always suits) $=4$ points. The highest scores are the indications of strong resilience. In the reliability-validity study, the internal consistency of the scale was retested through Cronbach alpha test and the Cronbach aplha coefficiency was calculated as 0.80 and the test-retest internal consistency coefficiency was calculated as 0.76 (Karairmak, 2007). The internal consistency of the dat in this research was subjected to Cronbach alpha test and its Cronbach alpha reliability coefficiency was calculated as 0.81 .

\section{The Life Satisfaction Scale}

The "Life Satisfaction Scale", developed by Diener (1984), and adapted into Turkish by Köker (1991) was used to specify PCG students' life satisfaction levels. The Scale consisted of 5 items in 7 ratings. The answers to the scale items were graded from 1 to 7 , as "I definitely disagree" 1 point and "I absolutely agree" = 7 points. High scores indicated to high life satisfaction. The reliability coefficiency of the scale was calculated as 0.73 .

The internal consistency of the data obtained in this study was confirmed through Cronbach alpha test and the coefficiency was calculated as 0.79 .

\section{Heartland Forgiveness Scale}

The participants' forgiveness levels were measured through Headland Forgiveness Scale, developed by Thomson et al., (2005). The scale was adapted into Turkish by Bugay \& Demir in 2010. The scale is 18 item-likert type with 7 gradings. Three sub-dimensions, "selfforgiveness", "forgiveness of other", and "forgiveness of the situation", with 6 questions in each composed the Headtland Forgiveness Scale. The answers were graded from 1 to 7 for positive and from 7 to 1 for negative propositions. The lowest point to be scored is 18 and the highest is 126. High scores in the scale and sub-dimensions indicate a high level of forgiveness. The Cronbach alpa coeffciency for the whole scale was calculated as 0.86 , for the sub-dimension of self forgiveness 0.75 , for forgiveness of others 0.78 , and forgiveness of the situation was 0.79 (Bugay \& Demir, 2010).

The Cronbach alpha value of the reliability test conducted by the researcher was found as 0.86 . The Cronbach alpha value for self forgiveness sub-dimension was 0.70 , foe forgiveness of others sub-dimension was 0.67 , and for forgiveness of the situation sub-dimension was 0.71 .

\section{Statistical Analysis of the Data}

The Statistical Package for Social Sciences (SPSS) 24.0 program was used in the analysis. The distribution of the responses according to the participants'socio-demographic characteristics, reslience scale, life satisfaction scale, and forgiveness scale were specified by frequency analysis. In addition, the average scores in the scale items and standard deviations were presented.

The average of the total points in resilience, life satisfaction scale, and forgiveness scale, standard deviation, the smallest and the biggest values were presented in descriptive statistics.

When specifying the hypothesis tests, the compatibility of the data set to normal distribution was examined through Kolmogorov-Smirnov test. The result revealed an incompatibility to the normal distribution. Therefore, in this research, non-parametric tests such as Mann - Whitney U 
test, Kruskal-Wallis test, and Speasrman correlation analysis were conducted. In the comparison of students' scores in resilience scale, life satisfaction scale, and forgiveness scale according to their gender and parental status (dead/alive..) Mann-Whitney U test, composed of two independent variables, was used. In the comparison of the scale tests in terms of family income, number of close friends, number of siblings, and birth order the Kruskal-Wallis test was conducted because the data set had 2 and more categories. At the end of the test differences and the source of the differences were examined through Man-Whitney $U$ test. The relationship among students' scores in resilience scale, life satisfaction scale, a nd forgiveness scale was analysed through Spearmen correlation analysis.

\section{Results}

This part of the study deals with the findings and the interpretations realted to the demographic characteristics of the prospective psychological counselors.

Firstly, to determine the differences in terms of gender, life satisfaction, resilience and forgiveness scores were analysed using Mann-Whitney U test (Table 2). A statistically significant difference was observed in life satisfaction scale in terms of gender $(p<0.05)$. Scores by the female $(=23,05+5,56)$ in life satisfaction scale were found significantly higher than that of scores by the male prospectives $(=21,20+6,34)$.

In terms of gender, the students' self forgiveness sub-dimension scores in the forgiveness scale indicated a statistically significant difference $(p<0.05)$. Female students' scores $(=24,49+5,82)$ in self forgiveness were found significally lower than that of males' scores $(=27,03+6,30)$. The scores by both sexes in forgiveness of others subdimenasion were statistically different $(p<0.05)$. Female students' scores $(=22,46+6,47)$ in the subdimensions of forgivness of others were significantly lower than that of males' scores $(=25,05+6,29)$. As for the sub-dimension of forgiveness of situation in terms of gender, a statistically significant difference was observed. $(\mathrm{p}<0.05)$. The female students' scores $(=24,5105+6,53)$ were significantly lower than that of males' scores $(=26,51+6,10)$. It was also observed that, in terms of gender, the difference between the scores in forgiveness scale was significantly significant $(\mathrm{p}<0.05)$; females' scores $(=71,00+16,23)$ were lower than the males' scores $(=78,58+16,14)$.

Table 2. Life satisfaction, resilience and forgiveness scores according to gender

\begin{tabular}{|c|c|c|c|c|c|c|}
\hline & Gender & $\mathbf{n}$ & $\bar{x}$ & $\mathbf{s}$ & $\mathbf{Z}$ & $\mathbf{p}$ \\
\hline \multirow{2}{*}{ Resilience } & Female & 116 & 40,53 & 5,67 & \multirow{2}{*}{$-0,139$} & \multirow{2}{*}{0,889} \\
\hline & Male & 118 & 39,88 & 7,06 & & \\
\hline \multirow{2}{*}{ Life Satisfaction } & Female & 116 & 23,05 & 5,56 & \multirow{2}{*}{$-2,269$} & \multirow{2}{*}{$0,023^{*}$} \\
\hline & Male & 118 & 21,20 & 6,34 & & \\
\hline \multirow{2}{*}{ Self-forgiveness } & Female & 116 & 24,49 & 5,82 & \multirow{2}{*}{$-3,297$} & \multirow{2}{*}{$0,001 *$} \\
\hline & Male & 118 & 27,03 & 6,30 & & \\
\hline \multirow{2}{*}{ Other-forgiveness } & Female & 116 & 22,46 & 6,47 & \multirow{2}{*}{$-3,190$} & \multirow{2}{*}{$0,001 *$} \\
\hline & Male & 118 & 25,05 & 6,29 & & \\
\hline \multirow{2}{*}{$\begin{array}{l}\text { Situation } \\
\text { Forgiveness }\end{array}$} & Female & 116 & 24,05 & 6,53 & \multirow{2}{*}{$-3,191$} & \multirow{2}{*}{$0,001 *$} \\
\hline & Male & 118 & 26,51 & 6,10 & & \\
\hline \multirow{2}{*}{ Forgiveness Total } & Female & 116 & 71,00 & 16,23 & \multirow{2}{*}{$-3,509$} & \multirow{2}{*}{$0,000 *$} \\
\hline & Male & 118 & 78,58 & 16,14 & & \\
\hline
\end{tabular}

While a significant difference was not observed in the level of resilience of the prospective Psychologial Counselors in terms of gender, a difference was noted in the levels of life satisfaction and forgiveness. The female students scores in life satisfaction compared to males was found higher. Contrary to this, the level of forgiveness of the male prospectives was found higher. This reveals that female students forgive less, but enjoy life more.
In order to analyze the life satisfaction, forgiveness and resilience scores based on the number of siblings, Kruskal-Wallis test was carried out (Table 3). This analysis revealed a statistically significant difference in the scores in life satisfaction scale $(\mathrm{p}<0.05)$. The results indicated that the students with no sibnlings scored higher points in life satisfaction scale compared to the ones with five or more siblings.

Table 3. Life satisfaction, forgiveness and resilience scores based on the number of siblings 


\begin{tabular}{|c|c|c|c|c|c|c|c|c|}
\hline & Number of siblings & $\mathbf{n}$ & $\overline{\boldsymbol{x}}$ & $\mathbf{s}$ & Mean Ranks & $\mathbf{X}^{2}$ & $\mathbf{p}$ & Difference \\
\hline \multirow{4}{*}{ Resilience } & Single child & 10 & 44,90 & 7,06 & 160,60 & 4,520 & 0,211 & \\
\hline & 1-2 siblings & 57 & 39,89 & 4,99 & 111,60 & & & \\
\hline & 3-4 siblings & 88 & 40,48 & 6,31 & 117,32 & & & \\
\hline & 5 or more siblings & 79 & 39,53 & 7,14 & 116,51 & & & \\
\hline \multirow{4}{*}{$\begin{array}{l}\text { Life } \\
\text { Satisfaction }\end{array}$} & Single child & 10 & 26,50 & 3,87 & 170,35 & 7,903 & $0,048 *$ & $1-5$ \\
\hline & 1-2 siblings & 57 & 21,93 & 5,55 & 115,85 & & & \\
\hline & 3-4 siblings & 88 & 22,66 & 5,70 & 120,98 & & & \\
\hline & 5 or more siblings & 79 & 21,10 & 6,67 & 108,12 & & & \\
\hline \multirow{4}{*}{$\begin{array}{l}\text { Self- } \\
\text { forgiveness }\end{array}$} & Single child & 10 & 23,70 & 5,91 & 98,60 & 3,490 & 0,322 & \\
\hline & 1-2 siblings & 57 & 24,93 & 4,81 & 107,56 & & & \\
\hline & 3-4 siblings & 88 & 26,72 & 6,46 & 126,25 & & & \\
\hline & 5 or more siblings & 79 & 25,58 & 6,71 & 117,32 & & & \\
\hline \multirow{4}{*}{$\begin{array}{l}\text { Other- } \\
\text { forgiveness }\end{array}$} & Single child & 10 & 22,40 & 6,47 & 107,20 & 0,878 & 0,831 & \\
\hline & 1-2 siblings & 57 & 23,46 & 5,82 & 114,13 & & & \\
\hline & 3-4 siblings & 88 & 23,81 & 7,35 & 116,17 & & & \\
\hline & 5 or more siblings & 79 & 24,11 & 6,03 & 122,72 & & & \\
\hline \multirow{4}{*}{$\begin{array}{l}\text { Forgiving the } \\
\text { situation }\end{array}$} & Single child & 10 & 25,30 & 6,22 & 121,05 & 0,367 & 0,947 & \\
\hline & 1-2 siblings & 57 & 25,07 & 5,01 & 113,09 & & & \\
\hline & $3-4$ siblings & 88 & 25,34 & 7,18 & 117,86 & & & \\
\hline & 5 or more siblings & 79 & 25,39 & 6,58 & 119,84 & & & \\
\hline \multirow{4}{*}{$\begin{array}{l}\text { Forgiveness } \\
\text { Total }\end{array}$} & Single child & 10 & 71,40 & 16,22 & 116,20 & 0,594 & 0,898 & \\
\hline & 1-2 siblings & 57 & 73,46 & 11,75 & 111,67 & & & \\
\hline & 3-4 siblings & 88 & 75,86 & 18,86 & 119,06 & & & \\
\hline & 5 or more siblings & 79 & 75,09 & 17,09 & 120,14 & & & \\
\hline
\end{tabular}

In terms of birth order, a statistically significant difference was found in the sub-dimension of forgiving others in forgiveness scale $(p<0.05)$. A single child's score was lower in the subdimension compared to the ones who were the third or fourth child.

The difference of the participants' scores in forgiveness scale, in terms of birth order, were statistically significant. The scores of the third child in forgiveness scale in general were higher compared to the first child's scores.

A difference was not noted in the levels of resilience and life satisfaction of the prospectives in terms of birth order variable, but the third child had a higher score in the sub-dimension of forgiving others. This indicates that the first child had a lower level of forgiving others compared to the third child.

Finally, Spearman correlation analysis was carried out to determine the relationship between life satisfaction, resilience and forgiveness scores (Table 4). The analysis showed statistically significant and positive correlations in students' scores in resilience scale and life satisfaction and forgiveness scales and the sub-dimensions of the forgivenes scale $(\mathrm{p}<0.05)$. This indicates that as the scores rise in resilience, the scores in life satisfaction, forgiverness, and in the subdimensions of the scale rise as well.

Table 4. The relationship between life satisfaction, resilience and forgiveness scores

\begin{tabular}{lllll}
\hline & & & &
\end{tabular}


(

\begin{tabular}{|c|c|c|c|c|c|c|c|}
\hline & $\mathrm{p}$ & $0,000^{*}$ & $0,002 *$ & & & & \\
\hline \multirow{2}{*}{ Other-forgiveness } & $\mathrm{r}$ & 0,215 & 0,112 & 0,520 & \multirow[t]{2}{*}{1,000} & & \\
\hline & $\mathrm{p}$ & $0,001 *$ & 0,088 & $0,000^{*}$ & & & \\
\hline \multirow{2}{*}{ Forgiving the situation } & $\mathrm{r}$ & 0,265 & 0,189 & 0,633 & 0,737 & 1,000 & \\
\hline & $\mathrm{p}$ & $0,000^{*}$ & $0,004 *$ & $0,000 *$ & $0,000^{*}$ & & \\
\hline \multirow{2}{*}{ Forgiveness Total } & $\mathrm{r}$ & 0,292 & 0,194 & 0,821 & 0,871 & 0,912 & 1,000 \\
\hline & $\mathrm{p}$ & $0,000^{*}$ & $0,003 *$ & $0,000 *$ & $0,000^{*}$ & $0,000 *$ & \\
\hline
\end{tabular}

$* \mathrm{p}<0.05$

Statistically significant correlatons were observed in the scores in life satisfaction and forgiveness scale in general and in the sub-dimensions of self forgiveness, forgiveness of others, and forgiveness of the situation $(p<0.05)$. These correlations are positive-sided and as the students scores are high in life satisfaction scale, their scores in forgiveness scale and the sub-dimensions of the scale are high as well. In summary, the results show that the prospective counselors' resilience, life satisfaction, and forgiveness levels are positively related. As their resilience rise, their life satisfaction rises too and similarly, parallel to the rise in their life satisfaction, their forgiveness levels go up.

\section{Discussion}

The findings in this research were discussed in the light of some studies in literature. $\% 49.57$ of the participant prospectives were female and $\% 50.43$ were male. A significant difference in the participants' resilience in terms of gender was not observed, altough in some studies it was argued that females have a higher level of resilience compared to males (Kumpfer, 1999).

When the life satisfaction rates of the participants are examined in terms of gender, female participants exhibited a higher level of life satisafaction. In some other studies the differences between gender and life satisfaction is rather low. Although women exhibit much more negative feelings, they enjoy their lives more (Yetim, 1991). Tuzgöl Dost (2007) investigated university studens' life satisfaction levels, percepted academic success, economical state, parents attitude, future expectations, religious beliefs, and loneliness variables. The results of the study pointed at a higher life satisfaction level in females than that of males. The similarities in our findings show that women have higher levels of life satisfaction.

The investigation in life satisfaction in terms of number of siblings showed that single children have a higher level of life satisfaction compared to the ones with five or more siblings. This makes us consider parent-child relationship, the level of interest in every child, and secure attachement. When the overall forgiveness scale and the sub- dimensions; self forgiveness, forgiveness of others, and forgiveness of the situation are exmined, a difference was not observed in terms of the number of siblings. The result of forgiveness and sub-dimensions in terms of gender showed that the sub-dimensions of self forgiveness in female students were lower compared to male students. This rersult reveals that male students are more self forgiving.

In terms of forgiveness, female PCG prospectives have a lower level in the sub-dimensions of forgiving others compared to male prospectives. In the light of these findings, it is assumed that female prospectives have low levels both in self forgiveness and forgiveness of others compared to male prospectives. As for the sub-dimensions of forgiveness of situation, it was observed that female students are less forgiving than male students. Enright (1996) argues that forgiving is a characteristic in which one has positive feelings and forgets voluntarily upsetting, hurting, and unfair individuals or events and replaces them with tenderness. Civan (2013), in a study examined cognitive distortions among people and the level of their forgiving others. The findings revealed that female students had higher scores in forgiving others than that of male students.

Significant positive correlations were observed in the levels of resilience, life satisfaction, and forgiveness of the prospectives, and the subdimensions in the scale. With respect to this, as the students' resilience level rises, there is an overall rise in their life satisfaction and forgiveness levels, as well as the sub-dimensions levels in the scale. In a study, Zhu (2015) investigated the mediating role of social support and balanced feelings in the relationship between forgiveness and life satisfaction. The results revelaed that, through the effect of social suport and balanced affectivity, forgiveness had an indirect effect on life satisfaction. Çapan \& Arıcıoglu (2014) investigated the facilitating power of resilience on forgiveness and spotted a relationship between students' resilience and forgiveness levels.

In general, positive-sided, significant correlations were specified in students' overall levels of life satisfacion, self forgiveness, forgiveness of others and the sub-dimensions of forgiveness of the 
situation. As students' life satisfaction levels rise, their overall forgiveness and the sub-dimensions levels in the scale rise accordingly.

\section{Conclusion and Suggetions}

The main aim of this research is to examine the relationship between resilience, life satisfaction, and forgiveness levels of prospective Psychological Counselors. The findings indicate a positive-sided relationship between resilience, life satisfaction, and forgiveness. It is observed that as the resilience levels of the participant prospectives rise, their life satisfaction levels rise accordingly. Similarly, their forgiveness levels rise parallel to the rise in their life satisfaction levels. In short, in case of a rise in any of the variables, a rise in the others is observed.

This research seeked answers to three subdimensions. The first was to specify any connetions between the prospective psychological counselors' resilience levels in terms of gender and number of siblings. The gender variable in terms of forgiveness level indicated that female participants' level in common forgiveness scale, self-forgiveness, forgiving others, the subdimensions of forgiving the situation had a lower level than male paricipants, which is an indication of males being more forgiving. mThe examination of the variable of number of siblings showed that single children had a higher level of life satisfaction compared to the ones with more than five siblings. In the case of birth order variable, it is observed that the third children had a higher level of forgiveness than the first born participants.

The second sub-dimension aim of this study was to examine any significant relationships between resilience and life satisfaction levels and a positive-sided relationship was noted. As in the second sub-dmension, in the third dimension, resilience and forgiveness levels were examined for any significant relationships and a positivesided relationship was observed.

In the light of the findings in general aims and sub-dimensions in this research, it is suggested that the prospective psychological counselors attend seminars and personal development training to rise their levels of resilience, life satisfaction, and forgiveness. Added to this, positive psychology can be a must and an optional course in the curriculum. Studies in consciousness and awarenes can urge the prospectives question their present situations, analyse it and contribute to their developments.

\section{References}

Al Tariq Z. Clinical, Biochemical and
Immunological Profiles of HIV Patients Developing Immune Reconstitution Inflammatory Syndrome (IRIS). Medbiotech Journal. 2018;02(01):21-8.

Amir Yaghoubi Nezhad SH, Atefeh Mehrabi Far, Masoumeh Piryaei, Seyed Mojtaba Mostafavi. Investigation of Shigella Lipopolysaccharides Effects on Immunity Stimulation of Host Cells. International Transaction Journal of Engineering, Management, Applied Sciences and Technologies. 2019;10:465.

Barbosa F. Emergency Health Care System and its Role in National Disasters. Journal of Humanities Insights. 2018;02(01):14-20.

Çapan, B.E \& Arıcioğlu, A (2014) Forgiveness, as a Facilitator of Resilience. International Educational Research Magazine

Civan, İ. (2013) A Study of Cognitive Distortions by University Students in Human Relations and forgiveness of others (Unpublished Post-study thesis). Adapted from the Center of National Thesis Database, Higher Education Committee (Thesis No: 349118)

Dost, T. M. (2007) An Investigation of University Students' Life Satisfaction In Terms of Some Variables. Educational Magazine, Faculty of Education, University of Pamukkale. 2(229, 132-143.

Eminağaoğlu, N. (2006). Durability of Homeless Children Under Difficult Conditions. (Unpunblished Ph.D. Thesis. The Institute of Social Science, Ege University

Enright, R. D. (1994). Piaget on the moral development of forgiveness: Identity or reciprocity?. Human Development, 37(2), 63-80.

Farzadnia E, Hosseini Z, Riahi A. Study of Hospital Quality Management and Improvement Rates in the Hospitals. Journal of Humanities Insights. 2017;01(01):7-11.

Hakiminya B, Parnian L. Examining the Relation between Life Style and General Mental Health. Journal of Humanities Insights. 2018;02(02):60-6.

Hall, J. H., \& Fincham, F. D. (2005). Selfforgiveness: The stepchild of forgiveness research. Journal of social and clinical psychology, 24(5), 621-637.

Karairmak, Ö. (2007). The Reliability and Validity of the Turkish Version of ConnorDavidson Resilience Scale. A Confirmatory Analysis of Trauma Samplings. IX. National psychological counceling and Guidance Booklet

Karasar, N. (2000). Scientific Research Method (19th Edition) Ankara: Nobel Publishing and Delivery

Köker, S. (1991). A comparison of the Level of Life Satisfaction of Normal and Problematic Adolescents. (Unpublished Ph.D Thesis. Institute of Social Sciences, University of Ankara).

Leung, C., \& Chan, W. (2016). SOCIỎLING̈UISTIC PHENOMENON OF CODE MIXING IN HONG KONG: FROM A PERSPECTIVE OF MARKETING COMMUNICATIONS. Humanities \& Social Sciences Reviews, 4(1), 20-26. 
Masten, A. S., Powell, J. L., \& Luthar, S. S. (2003). A resilience framework for research, policy, and practice. Resilience and vulnerability: Adaptation in the context of childhood adversities, $1,25$.

McCubbin, L. (2001). Challenges to the Definition of Resilience. Paper presented at the Annual Meeting of the American Psychological Association San Francisco, CA, August 24-28.

Mehrabifar A, Mansouri A, Gholami K, Ghaeli P, Javadi M. Investigation of Medication Errors in a Teaching Psychiatric Hospital using Chart Reviews. Medbiotech Journal. 2017;01(02):60-4.

Mostafavi SM, Eissazadeh S, Piryaei M. Comparison of Polymer and Ceramic Membrane in the Separation of Proteins in Aqueous Solution Through Liquid Chromatography. Journal of Computational and Theoretical Nanoscience. 2019;16(1):157-64.

Murray, C. (2003). Risk factors, protective factors, vulnerability, and resilience: $A$ framework for understanding and supporting the adult transitions of youth with high-incidence disabilities. Remedial and special education, 24(1), 16-26.

Özgen, F. (2012). An Investigation of Life Satisfaction Levels of Physical Educatin and Sports High School Students. Ph.D Graduation Thesis, 18 Mart University, Çanakkale

Samira Eissazadeh MP, Mohammad Sadegh Taskhiri, Mostafavi SM. Improvement of Sensitivity of Antigen-Antibody Detection of Semen Through Gold Nanoparticle. Research Journal of Pharmaceutical, Biological and Chemical Sciences. 2019;10(1): 144 .

Sarıcaoğlu, H. (2011). A Study of university students' favourable level of psyhological state in terms of personal charcteristics and self-perceptiveness. Ph.D Dissertation, Institute of Educational Sciences, Selçuk University

Thompson, L. Y., Snyder, C. R., Hoffman, L., Michael, S." T., Rasmussen, H. N., Billings, L. S.. ... \& Roberts, D. E. (2005). Dispositional forgiveness of self, others, and situations. Journal of personality,73(2), 313-360.

Villalobos, J. V. (2018). Politics as a requirement. On the concept of Human Rights and the right to an autobiography as an ethical category. Opción, 34(85-2), 9-19.

Yetim, Ü. (1991) Life Satisfaction in Terms of Personal Project Organization (Unpublished Ph.D Thesis, Institute od Social Sciences, Ege University, Izmir).

Yetim, Ü. (2001), Life Satisfaction in Terms of Personal Project Organization. Institute of Social Sciences, Ege University

Zendegany S. Social and civil perceived supports for kidney patients compared to normal people. Journal of Humanities Insights. 2019;3(01):17-9. 